Мобільність студентів у виборі рівня сприяє мотивації студентів 3 високим рівнем домагань до самоактуалізації та самонавчання; студенти вчаться самоконтролю, самооцінці й самоуправлінню завдяки можливості самостійно обирати рівень завдань, зіткнувшись 3 труднощами або, навпаки, недостатньою складністю завдань; і мають змогу самостійно організовувати пошук потрібної навчальної інформації.

Використовуючи різнорівневі завдання для організації самостійної роботи студентів, спонукаємо їх до систематичної самоосвітньої діяльності й активізації процесів САМО (самоактуалізації, самонавчання, самоконтролю, самооцінки, самоуправління і самоорганізації), що є запорукою у формуванні конкурентоздатного фахівця, який відповідає вимогам сучасного роботодавця. Подальші дослідження вбачаємо у вдосконаленні реалізації функцій управління самоосвітньою діяльністю студентів інженерних спеціальностей.

\title{
Література
}

1. Квітка Т. В. Методичні вказівки до вивчення теми «Невизначений інтеграл» 3 дисципліни «Вища математика» для студентів технічних спеціальностей всіх форм навчання 3 різнорівневими завданнями / Т. В. Квітка. - Кривий Ріг : Видавничий центр ДВНЗ «КНУ», 2013. - 28 с. 2. Малихін О. В. Організація самостійної навчальної діяльності студентів вищих педагогічних навчальних закладів: теоретико-методологічний аспект: [монографія] / О. В. Малихін. - Кривий Ріг : Видавничий дім, 2009. - 307 с. 3. Митина Л. М. Психология здоровья человека в глобализирующемся мире: системный личностно-развивающий подход [Электронный $\quad$ pecypc] / $\quad$ Л. М. Митина. - Режим доступа: http://www.enu.kz /repository2014/psihologia-zdorvya.pdf 4. Навчальна програма 3 дисципліни «Вища математика» для студентів напряму підготовки 6.050701 «Електротехніка та електротехнології». - Кривий Ріг : ДВНЗ «Криворізький національний університет», 2012. 20 с. 5. Пидкасистый П. И. Организация учебно-познавательной деятельности студентов / П. И. Пидкасистый. - Москва : Педагогическое общество России, 2005. - 144 с. 6. Рашкевич Ю. М. Болонський процес та нова парадигма вищої освіти: [монографія] / Ю. М. Рашкевич. - Львів : Видавництво Львівської політехніки, 2014. - 168 с. 7. Робоча навчальна програма 3 дисципліни «Вища математика» для студентів напряму підготовки 6.050701 «Електротехніка та електротехнології».- Кривий Ріг: ДВНЗ «Криворізький національний університет», 2013. - 70 c. 8. Солдатенко М. М. Проблеми управління навчально-пізнавальною діяльністю учнів і студентів / М. М. Солдатенко. - Режим доступу: http://lib.iitta.gov. ua/ id/eprint/2905

Любов Клюй

\section{СТРУКТУРУВАННЯ ЗМІСТУ НАВЧАЛЬНОГО МАТЕРІАЛУ КУРСУ ЗА ВИБОРОМ У ПРОЦЕСІ ФАХОВОЇ ПІДГОТОВКИ МАЙБУТНІХ СОЦАЛЬНИХ ПЕДАГОГІВ}

Клюй Л. В. Структурування змісту навчального матеріалу курсу за вибором у процесі фахової підготовки майбутніх соціальних педагогів.

У статті порушено питання розроблення дидактичного супроводу в умовах соціальнопедагогічної підготовки майбутніх соціальних педагогів у змісті курсу за вибором. Дидактичний супровід щодо основних напрямків соціально-педагогічної діяльності певною мірою нівелює перевагу теоретичного блоку дисциплін над практичним, пов'язаним із формуванням фахових умінь і навичок, сприяючи виробленню проективних умінь і навичок 
майбутніх фахівців.

Ключові слова: соціально-педагогічна підготовка, соціальні педагоги, дидактичний супровід, соціально-педагогіна діяльність, курс за вибором.

Клюй Л. В. Структурирование содержания учебного материала курса по выбору в процессе профессиональной подготовки будущих социальных педагогов.

В статье рассматривается вопрос разработки дидактического сопровождения в условиях социально-педагогической подготовки будущих социальных педагогов в содержании курса по выбору. Дидактическое сопровождение касательно основных направлений социально-педагогической деятельности в некоторой степени нивелирует преимущество теоретического блока дисциплин над практическим, который связан с формированием профессиональных умений и навыков, активизируя формирование проективных умений и навыков будущих специалистов.

Ключевые слова: социально-педагогическая подготовка, социальные педагоги, дидактическое сопровождение, социально-педагогическая деятельность, курс по выбору.

Kliuy L. V. Structuring the contents of elective course material in the process of professional training of future social teachers.

The article studies the issues of didactic maintenance development for the contents of elective course in terms of socio-pedagogical training of future social teachers. Didactic maintenance as to the main directions of socio-educational activities to some extent offsets the advantage of theoretical course units against the practical one. The last one is associated with the formation of professional abilities and skills enhancing the formation of projective skills of future specialists.

Key words: social and pedagogical training, social teachers, didactic maintenance, social and educational activities, elective course.

На сучасному етапі розвитку вітчизняної освіти здійснення практичної підготовки соціальних педагогів має свою фахову специфіку, зумовлену соціокультурним процесом становлення і розвитку фаху соціального педагога. Підготовка фахівців для соціальнопедагогічної галузі у вищих навчальних закладах України має достатньо молодий вік, тому однією з актуальних науково-практичних проблем, яка потребує розроблення теоретичних $\mathrm{i}$ технологічних засад, $є$ процес підвищення професійного рівня фахівців. Суттєвим, з огляду на професіоналізацію, $є$ практичне навчання студентів, зорієнтоване на формування необхідних фахових умінь і навичок, становлення стійкої мотивації активної фахової діяльності загалом і розроблення варіативної частини у структурі змісту навчання майбутніх фахівців зокрема.

Проблеми змісту освіти досить широко висвітлено в сучасній педагогічній науці. Зокрема, розроблено питання змісту освіти як системи, іiі структури (В. Краєвський, В. Ледньов, І. Лернер та інші), схарактеризовано рівні змісту освіти (І. Журавльов, І. Лернер, В. Раєвський та інші), сформульовано принципи добору змісту освіти (В. Краєвський, В. Ледньов, М. Скаткін, Н. Тализіна та інші), обгрунтовано принципи, виокремлено критерії та способи оптимізації змісту освіти на різних рівнях (А. Ашеров, Ю. Бабанський, В. Беспалько, Б. Гершунський, С. Гончаренко, О. Новиков, І. Підласий та інші).

Розвідки І. Беха, О. Беспалько, А. Капської [О. Кузьменка, І. Миговича, Л. Міщик, В. Оржеховської розкривають суперечливі питання соціальної дійсності, які характеризують 
проблеми сучасного соціуму й окремі аспекти їх розв'язання соціальними педагогами й соціальними працівниками.

Актуальність проблеми щодо розроблення теорії і практики вивчення навчальних курсів галузі знань «Соціальна педагогіка» засвідчує низка наукових розвідок. Особливості цих навчальних курсів, а також психолого-педагогічні аспекти їх використання в навчальному процесі розкрито в дослідженнях В. Бочарової, М. Гур'янової, Н. Шмельової, Є. Холостової. Питання підготовки і професійного становлення соціальних педагогів та соціальних працівників розглянуто у працях С. Архипової, Л. Гуслякової, І. Козубовської, В. Масленникової, В. Сластьоніна, С. Тетерського, С. Чистякової, Н. Шмельової та інших.

Значним недоліком навчальних планів і програм підготовки соціальних педагогів у вищих навчальних закладах $є$ перевага теоретичного блоку дисциплін над практичним, пов'язаним із формуванням умінь і навичок. Також слід констатувати, що нині не набула поширення загальна концепція щодо практичної підготовки соціальних педагогів.

Mema cmammi - визначити змістове наповнення курсу за вибором у процесі фахової підготовки майбутніх соціальних педагогів.

Зміст характеристик, яким повинен відповідати випускник вищого закладу освіти, зосереджено в освітньо-кваліфікаційній характеристиці бакалавра, спеціаліста, магістра за певним напрямом підготовки. На першому етапі у структуруванні змістового блоку навчального курсу здійснюється у процесі формування галузевих стандартів вищої освіти у вигляді освітньо-кваліфікаційних характеристик та освітньо-професійних програм.

Освітньо-кваліфікаційна характеристика містить спеціальний розділ, у якому надається перелік виробничих функцій, типових задач діяльності та умінь щодо розв'язання типових задач діяльності. Визначено продукт праці (кінцевий результат, ціль праці); предмет, на який спрямована праця фахівця (матеріал, механізм, природний об'єкт, людина тощо); засоби праці (машини, механізми, інші знаряддя праці); процедури (способи) праці (технологія, процес діяльності, організація тощо); умови, у яких відбувається праця фахівця. На основі аналізу змісту типових задач діяльності формується система вмінь, яка містить інформацію про зміст кожної виробничої функції, назви типових задач, характерних для неї, шифри та зміст умінь, які необхідні фахівцю для розв'язання типових задач, з визначенням необхідного рівня сформованості кожного з них.

Вимоги до соціально значущих властивостей i якостей випускника вищого навчального закладу наводяться у вигляді переліку здатностей розв'язувати певні проблеми й задачі соціальної діяльності та системи умінь, що $є$ відображенням наявності цих здатностей.

В освітньо-професійній програмі визначається нормативний зміст навчання, встановлюються вимоги до змісту, обсягу й рівня освітньої та професійної підготовки навчання фахівця відповідного освітньо-кваліфікаційного рівня певної спеціальності.

Отже, зміст освітньо-професійної програми має передбачати змістові модулі, що встановлює відповідність між змістом конкретних умінь (з встановленим необхідним рівнем його засвоєння), назвою змістовних модулів, що забезпечують їх формування, та мінімальною кількістю годин (кредитів) для вивчення кожного модуля. Змістові модулі об'єднуються у блоки змістовних модулів, для яких регламентується мінімальна кількість навчальних годин (кредитів) їх вивчення. Освітньо-професійна програма містить перелік навчальних дисциплін із зазначенням блоків змістових модулів, а також мінімальну кількість годин (кредитів) для вивчення кожної навчальної дисципліни.

Процес окреслення меж предметної (соціально-педагогічної) галузі для формування 
змістового блоку навчальних курсів (дисциплін) на основі діяльнісного підходу уможливлює розв'язання таких задач:

- розробляти та коригувати навчальні плани та програми навчальних курсів (дисциплін) інваріантної і варіативної частин;

- розробляти засоби діагностування рівня освітньо-професійної підготовки фахівця;

- визначати зміст навчання як базу для опановування новими спеціальностями, кваліфікаціями;

- визначати зміст навчання в системі перепідготовки та підвищення кваліфікації;

- визначати нормативний термін навчання;

- аналізувати наявні міжпредметні зв'язки.

Тематична модель курсів за вибором, використовувана у практиці вищої школи як перелік розділів і тем, що підлягають вивченню (типові та робочі програми навчальних курсів), у процесі підготовки майбутніх соціальних педагогів має відображати загальну структуру навчального курсу, яка потребує подальшої конкретизації.

Наводимо фрагмент курсу за вибором, який конкретизує й поглиблює загальний курс «Основи соціальної роботи» у змісті психолого-педагогічної підготовки майбутніх соціальних педагогів.

\section{Змістовий модуль «Поняття соціальної роботи. \\ Система соціальної роботи в Україні» курсу за вибором «Інноваційні аспекти вітчизняної соціально-педагогічної роботи».}

Тема 1: Соціальна робота як наука та практична діяльність (2 год.)

1. Наукові школи соціальної педагогіки: інноваційні етапи розвитку.

2. Сутність соціальної роботи. Основні поняття соціальної роботи: виховуючи середовище, сочіальне середовище, соціалізащія, сочіальне виховання.

3. Об'єкт і предмет соціальної роботи.

4. Функції та принципи соціальної роботи.

5. Сутність глобалізаційного характеру прикладної соціально-педагогічної науки.

Тема 2: Основні напрямки соціальної роботи (2 год.)

1. Основні шляхи подолання бідності:

- створення економічно-правових умов для збільшення доходів i зростання економічної активності працездатних громадян;

- підвищення ефективності соціальної підтримки найбільш уразливих груп населення шляхом реформування системи соціального захисту;

- політика подолання бідності має поєднуватися з політикою становлення середнього класу.

2. Збільшення доходів від трудової діяльності.

3. Соціальне страхування як спосіб захисту особи від втрат доходу.

4. Запровадження консолідованої системи адресної соціальної допомоги та соціальних послуг.

5. Соціальна підтримка осіб з обмеженими фізичними можливостями.

6. Соціальна підтримка сімей з дітьми та дітей, позбавлених батьківського піклування.

7. Поліпшення житлових умов соціально вразливих верств населення.

Тема 3: Методи соціальної роботи. Соціологічні, педагогічні і психологічні методи в соціальній роботі (2 год.)

Основні підходи до класифікації методів соціальної роботи. 
Загальна характеристика методів соціальної роботи:

\begin{tabular}{|l|l|}
\hline \multicolumn{1}{|c|}{$\begin{array}{c}\text { Основна } \\
\text { класифікація }\end{array}$} & \multicolumn{1}{|c|}{ Вирізнювані методи чи групи методів } \\
\hline $\begin{array}{l}\text { 1. Ступінь } \\
\text { спільності } \\
\text { клієнтів }\end{array}$ & $\begin{array}{l}\text { 1.1. Методи індивідуальної соціальної роботи. } \\
\text { 1.2. Методи групової соціальної роботи. }\end{array}$ \\
\hline $\begin{array}{l}\text { 2. Зміст } \\
\text { характер } \\
\text { соціальної } \\
\text { роботи }\end{array}$ & $\begin{array}{l}\text { 2.1. Група соціально-економічних методів соціальної роботи. } \\
\text { 2.2. Група організаційно-розпорядчих методів соціальної роботи. }\end{array}$ \\
\hline $\begin{array}{l}\text { 3. Сфера } \\
\text { застосування: } \\
\text { виховання } \\
\begin{array}{l}\text { підростаючого } \\
\text { покоління }\end{array}\end{array}$ & $\begin{array}{l}\text { 3.1. Метод стимулювання і залучення до дії. } \\
\text { 3.3. Метод репродукування. }\end{array}$ \\
\hline
\end{tabular}

3. Методи соціальної роботи в загальноосвітньому навчальному закладі.

4. Загальні методи впливу на клієнта.

Тема 4: Поняття технологізації в системі соціальної роботи. Технології соціальної роботи (2 год.)

1. Сутність технологічного підходу в сучасній соціальній діяльності.

2. Структурно-логічна схема технологій соціальної роботи.

3. Соціальне діагностування. Оцінка ефективності соціальної роботи.

4. Інформаційні й комунікаційні технології в системі соціальної роботи.

5. Технології соціального проектування в системі соціальної роботи.

6. Технології індивідуальної соціальної роботи.

7. Технології групової соціальної роботи.

8. Технології організації роботи у громаді.

Тема 5: Поняття соціалізації й адаптації в соціальній роботі як взаємопов'язаних механізмів (2 год.)

Поняття про адаптацію, соціальну адаптацію. Теоретичні концепції соціальної адаптації особистості. Взаємозв'язок адаптації й соціалізації. Фактори, що впливають на успішність адаптаційного процесу.

Особливості соціальної адаптації на макро-, мезо- і макрорівнях.

Взаємозв'язок біологічного, психологічного і соціального рівнів адаптації. Механізми адаптації: захисні, незахисні, змішані.

Класифікація адаптації: нормальна, девіантна та патологічна адаптація.

Стратегії адаптації: конформізм, акомодація, асиміляція.

Критерії та показники адаптованості (засвоєння та виконання соціальних ролей, продуктивність праці, задоволеність життям).

Поняття про соціальну дезадаптацію і соціально-психологічну дезадаптацію, їх прояви та причини.

Тема 6: Соціальна профілактика (2 год.)

Поняття соціальної профілактики.

Профілактика негативних явищ у молодіжному середовищі.

Профілактика бездоглядності і безпритульності. Соціальна робота з дітьми вулиці.

Профілактика насильства над дітьми. 
Профілактика соціального сирітства. Соціальна підтримка сімей із дітьми.

Тема 7: Соціальна реабілітація (2 год.)

Поняття про соціальну реабілітацію. Мета і критерії ефективності соціальної реабілітації.

Види соціальної реабілітації. Медична, соціально-середовищна, професійно-трудова та психолого-педагогічна реабілітація.

Індивідуальна програма реабілітації. Методи соціальної реабілітації.

Порівняльна характеристика технологій соціальної адаптації й соціальної реабілітації.

Особливості соціальної реабілітації різних груп населення.

Тема 8: Сфери діяльності соціального працівника. Система соціальних послуг (2 год).

Соціальні послуги: основні форми та види.

Структура сфери надання соціальних послуг.

Фінансування соціальних послуг в Україні.

Кліснти соціальної роботи.

Сфери практичної соціальної роботи.

Завдання проблемного характеру:

Заповнити таблицю:

\begin{tabular}{|l|l|l|l|l|}
\hline$№$ & $\begin{array}{l}\text { Методи } \\
\text { соціальної роботи }\end{array}$ & $\begin{array}{l}\text { Соціальні групи, } \\
\text { кліснти }\end{array}$ & $\begin{array}{l}\text { Соціальні установи, } \\
\text { соціальні працівники }\end{array}$ & $\begin{array}{l}\text { Орієнтовні } \\
\text { форми роботи }\end{array}$ \\
\hline & & & & \\
\hline
\end{tabular}

Написати додаткові характеристики кваліфікаційних ознак у таблицю:

\begin{tabular}{|l|l|}
\hline \multicolumn{1}{|c|}{ Загальна технологія } & Характеристика \\
\hline Соціальна діагностика & \\
\hline Соціальна профілактика & \\
\hline Соціальна адаптація & \\
\hline Соціальна реабілітація & \\
\hline Соціальна корекція і терапія & \\
\hline Соціальне проектування & \\
\hline Соціальне прогнозування & \\
\hline $\begin{array}{l}\text { Соціальна експертиза та оцінка } \\
\text { ефективності }\end{array}$ & \\
\hline Соціальне посередництво & \\
\hline Соціальне консультування & \\
\hline Соціальне забезпечення & \\
\hline Соціальне страхування & \\
\hline Соціальна опіка та піклування & \\
\hline
\end{tabular}

Здійснити аналіз і заповнити таблицю:

\begin{tabular}{|c|c|c|}
\hline № п/п & $\begin{array}{c}\text { Міждисциплінарна } \\
\text { технологія }\end{array}$ & Особливості застосування в соціальній роботі \\
\hline & & \\
\hline
\end{tabular}

\section{Література}

1. Верхола А. П. Дидактические основы оптимизации процесса обучения дисциплинам вуза: автореферат дис. на соискание ученой степени д-ра пед. наук: спец. 13.00.01 «Теория и история педагогики»/ А. П. Верхола. - Киев, 1989. - 49 с. 
2. Кларин М. В. Педагогические технологии в учебном процессе. Анализ зарубежного опыта / М. В. Кларин. - Москва : Знание, 1989. - 80 с.

УДК $378.016: 537.8$

Олександр Коновал

\section{СУПЕРЕЧНОСТІ У ТРАДИЦІЙНЙ МЕТОДИЦІ НАВЧАННЯ ЕЛЕКТРОДИНАМІКИ}

Коновал О. А. Суперечності у традиційній методиці навчання електродинаміки.

У статті здійснено теоретичний аналіз традиційних підходів до вивчення електродинаміки, звернуто увагу на суперечності, які виникають під час застосування класичного закону Біо-Савара i вибору умови нейтральності провідника 3 постійним струмом.

Ключові слова: закон Біо-Савара, умова нейтральності провідника 3 постійним струмом, методика навчання електродинаміки.

Коновал О. А. Противоречия в традиционной методике преподавания электродинамики.

В статье осуществлен теоретический анализ традиционных подходов к преподаванию электродинамики, обращено внимание на противоречия, которые возникают при применении классического закона Био-Савара и условия нейтральности проводника с постоянным током.

Ключевые слова: закона Био-Савара, условие нейтральности проводника с постоянным током, методика преподавания электродинамики.

Konoval A. A. Contradictions in the traditional methods in teaching electrodynamics.

The article deals with the theoretical analysis of the traditional approaches to electrodynamics teaching. The author has paid attention to the contradictions arising in the process of application of the classical Biot-Savart`s law and the neutrality conditions of the conductor with a constant current.

Key words: Biot-Savart's law, neutrality condition of the conductor with a constant current, teaching methods of electrodynamics.

Розвиток сучасної фізичної науки висуває низку нових вимог до фахової підготовки студентів-фізиків, що потребує оволодіння ними системою сучасних наукових знань. Виконання цих вимог стає можливим за умови вдосконалення методики вивчення фізики на засадах принципу фундаменталізації (ПФ).

Однак звернення до сучасних посібників з теоретичної фізики та загального курсу фізики [1-14], шкільного курсу фізики засвідчує, що в інтерпретації окремих законів, питань в методиці навчання електродинаміки мають місце суперечності та питання дискусійного характеру, які заважають формуванню у студентів цілісної картини адекватних уявлень щодо системи основних законів електродинаміки. Наш багаторічний досвід засвідчує, що наявність цих суперечностей викликає особливі труднощі у студентів при самостійному опрацюванні навчального матеріалу.

У зв'язку з цим метою статті визначено: здійснення теоретичного аналізу сучасних методичних підходів у процесі викладання електродинаміки, виявлення суперечностей i проблемних питань у теорії та методиці навчання електродинаміки й окреслення перспектив їх розв'язання. 